\title{
PENGERTIAN DAN CIRI UTAMA KAPITALISME
}

\author{
DEWI/90100118101
}

EKONOMI ISLAM C

Kapitalisme berasal dari asal kata capital yaitu berarti modal, yang diartikan sebagai alat produksi semisal tanah dan uang. Sedangkan kata isme berarti paham atau ajaran. Kapitalisme muncul di Eropa pada abad ke-16. Secara sosiologis paham kapitalisme berawal dari perjuangan terhadap kaum feodal. Kapitalisme awal dimulai dengan lahirnya institusi pasar (market) pada abad ke-16 dan dilanjutkan dengan perkembangan perdagangan jarak jauh antar pusat-pusat kapitalisme dunia. Pada akhir abad pertengahan (abad 16 sampai 18), Industri di Inggris sedang terkonsentrasi pada industri sandang. Kapitalisme merupakan sitem ekonomi politik yang cenderung ke arah pengumpulan kekayaan secara individu tanpa gangguan kerajaan. Dengan kata lain kapitalisme adalah suatu paham ataupun ajaran mengenai segala sesuatu yang berhubungan dengan modal atau uang. Kapitalisme juga diartikan sebagai suatu sistem yang memberikan kebebasan penuh bagi setiap individu dalam menjalankan kegiatan ekonominya di pasar tanpa campur tangan pemerintah. Pada sistem ekonomi ini terdapat keleluasaan bagi perorangan untuk memiliki sumber daya, seperti kompetisi antar individu dalam memenuhi kebutuhan hidup, persaingan antar badan usaha dalam mencari keuntungan. Prinsip "Keadilan" yang dianut oleh ekonomi kapitalis adalah setiap orang menerima imbalan berdasarkan prestasi kerjanya. Dalam hal ini campur tangan pemerintah sangat minim, sebab pemerintah berkedudukan sebagai "Pengamat" dan "Pelindung" dalam perekonomian (Itang dan Adib Daenuri, 2017).

Pengertian lain menyebutkan, kapitalisme, sesuai asal katanya kapital yang berarti modal, ialah sistem perekonomian yang menganggap modal sebagai penggerak perekonomian. Kapitalisme mengakui kekuasaan kaum pemodal (kapitalis) sebagai motor perekonomian yang menanamkan modalnya dengan mengambil resiko kerugian atas usahanya. Pasar yang dikehendaki sebagai alokator interaksi supply dan demand yang sempurna dan efisien adalah mekanisme pasar bebas. Maksudnya, biarkan saja perekonomian berjalan dengan wajar tanpa campur tangan pemerintah, sebab nanti akan ada tangantangan tak terlihat (invisible hands) yang akan membawa perekonomian tersebut ke arah keseimbangan. Adam Smith sebagai pelopor sistem ini, menganjurkan peran negara 
seminimal mungkin dan mengusahakan seluas-luasnya kebebasan bagi para pelaku ekonomi yang mengandalkan self-interest-nya. Inilah konsep laissez faire-laissez passer ala kaum fisiokrat yang berawal dari pendapat Francis Quesnay (Choirul Huda, 2016).

Ernest Mandel dalam buku Bagong Suyanto yang berjudul "Sosiologi Ekonomi: Kapitalisme dan Konsumsi di Era Masyarakat Post Modernisme" membahasa lebih perinci dan mengajukan lima ciri pokok dari ekonomi kapitalisme. Pertama, ditingkat produksi, corak kapitalis adalah produksi komoditas, untuk meraih keuntungan yang sebesarbesarnya. Kedua, produsksi dilandasi kepemilikan pribadi. Ketiga, produksi dioperasinalkan dalam rangka meraih mengusai pasar yang berada dibawah kendali persaingan. Keempat, para kapitalis berupaya merauk keuntungan yang sebesar-besarnya dengan cara melakukan. Kelima, Tujuan terakhir dari porduksi adalah akumulasi kapital (Sirajuddin dan Tamsir, 2019).

Berdasarkan penjelasan diatas, menurut penulis bahwa kapitalisme adalah suatu paham dimana kegiatan ekonomi dilakukan hanya bertujuan untuk mendapatkan keuntungan saja tanpa memandang dari segi kehalalan proses keuntungan itu didapatkan. Kebebasan kepemilikan individu menurut pemahaman kapitalisme adalah suatu sistem dimana setiap individu bebas memiliki semua sumber daya alam tanpa membedakan antara harta yang merupakan hak individu, masyarakat maupun negara. Alasannya karena dalam paham kapitalisme konsep kepemilikan harta adalah milik semua orang, artinya bahwa setiap orang diberi kebebasan secara mutlak untuk mengelola maupun memanfaatkan harta tersebut. Hal ini tentunya bertentangan dengan konsep kepemilikan harta dalam Islam, dimana Islam mengajarkan bahwa pada esensinya semua harta yang ada dalam alam semesta ini adalah milik Allah subuhanahu wa ta'ala sehingga manusia hanyalah sebagai pengelola dan pengembang dari harta yang ada dengan tetap terikat dengan aturan syariat. Islam juga membolehkan setiap individu untuk memiliki harta namun harus diketahui bahwa selain kepemilikan individu, juga ada kepemilikan harta atas umum dan negara. sehingga dengan konsep ini, harta yang Allah subuhanahu wa ta'ala ciptakan untuk hambaNya bisa bermanfaat bagi semua orang. Berbeda dengan kapitalisme yang memandang perlunya akumulasi kapital untuk memperkaya diri sehingga kekayaan hanya bisa dinikmati oleh segelintir orang saja.

Tidak hanya itu, padangan kapitalisme yang beranggapan bahwa pemerintah tidak perlu berperan secara aktif dalam kegiatan ekonomi dimana pemerintah hanya sebagai 
pengamat, bahwa hal ini bisa saja menimbulkan penyimpangan dalam pasar karena Kekuatan pasar yang bebas tidak dengan sendirinya menghasilkan kondisi ekonomi pasar yang adil. Mekanisme pasar yang bebas tidak bisa menghentikan spekulasi harga, mencegah eksploitasi dan tidak menolong mereka yang lemah, baik konsumen maupun pedagang kecil. Oleh karena itu, negara harus berperan secara aktif. Peranan positif negara ini tidak dapat disamakan dengan apa yang dikenal dengan intervensi dalam terminologi kapitalis. Dengan kata lain, menurut Islam peranan negara sangat penting terutama dalam mengendalikan harga pasar. Masyarakat boleh menentukan harga pasar tetapi tidak bebas. Jika kebebasan itu lalu menimbulkan kerusakan atau kesulitan bagi masyarakat, maka pemerintah mempunyai hak untuk menertibkannya (Siti Mujiatun, 2014). 


\section{DAFTAR PUSTAKA}

Huda, C. (2016). Ekonomi Islam Dan Kapitalisme (Merunut Benih Kapitalisme Dalam Ekonomi Islam). Economica: Jurnal Ekonomi Islam, 7 (1), 27-49.

Itang, I., \& Daenuri, A. (2017). Sistem Ekonomi Kapitalis, Sosialis, Dan Islam. Tazkiya, 18(01), 67-91.

Mujiatun, S. (2014). Peran Pemerintah Tentang Pengembangan Perekonomian Dalam Perspektif Sistem Ekonomi Kapitalis, Sosialis, Dan Islam. Jurnal Analytica Islamica, 3, 90-107.

Sirajuddin, S., \& Tamsir, T. (2019). Rekonstruksi Konseptual Kepemilikan Harta Perspektif Ekonomi Islam (Studi Kritis Kepemilikan Harta Sistem Ekonomi Kapitalisme). Laa Maisyir: Jurnal Ekonomi Islam, 6(2), 211-225. 